\title{
Global Climate Change, Threat to Food Safety and Poverty
}

\author{
Kola O. Odeku \\ Faculty of Management and Law, School of Law, \\ University of Limpopo, South Africa \\ E-mail:kooacademics@gmail.com
}

\section{Doi:10.5901/mjss.2013.v4n14p827}

\begin{abstract}
Climate change is already threatening the safety of the world's food supplies and unless action is taken, it is going to get worse. Extreme weather conditions such as droughts and heavy rains are affecting agricultural productivity, and in some areas staple foods that are important to poor households in developing countries are being wiped out, resulting in higher prices to the consumers and lower income to the farmers. Considering that food is a major expenditure for the poor, this paper examines strategic interventions approaches that assures food security, foster emissions reduction to mitigate and adapt to climate change in order to reduce hunger and poverty.
\end{abstract}

Keywords: Climate change, Food insecurity, Poverty, Strategic Interventions, Agriculture, Sustainability

\section{Introduction}

Tackling climate change is perhaps the major environmental challenge we face today (Adger et al. 2009). Developing countries are particularly vulnerable to the impacts of the changing climate because of their high dependence on natural resources and limited capacity to cope with the impacts (Kelly and Adger 2000). The nexus of climate change, agriculture and food security is one of the quintessential challenges of sustainable development (Storm, 2009). Rapid growth in many of the world's populations and economies is increasing the demand for food, energy, fiber, water and land for housing but efforts to meet these and other essential human needs are transforming the global environment and driving dangerous changes in the world's climate (Nellemann, 2009).

Climate change and poverty pose serious challenges to the present and future generations and these challenges must be addressed in order not to escalate already tensed situation in developing countries especially and the whole world at large (Brusasco-Mackenzie, 2002). Changing rainfall patterns caused by consequences of climate change are devastating rain-fed agriculture on which so much of the population in poor countries depend on to survive (Fischer et al. 2002).

Food and Agriculture Organisation (FAO, 2008) defined food security as a "situation when all people, at all times, have physical, social and economic access to sufficient, safe, and nutritious food that meets their dietary needs and food preferences for an active and healthy life." Food security is not narrowly defined as whether food is available, but whether the monetary and non-monetary resources at the disposal of the population are sufficient to allow everyone access to adequate quantities and qualities of food (Hofisi, 2013). Scientific reports have revealed that all dimensions of food security are likely to be affected by climate change. Importantly, food security will depend not only on climate and socioeconomic impacts on food production, but also on economic growth, changes to trade flows, stocks, and food aid policy (Gregory et al. 2005). Food security which is an outcome of food system processes all along the food chain is affected by climate change through its impacts on all components of global, national and local food systems (FAO, 2008). Climate change also has serious negative impacts on the four dimensions of food security: food availability, food accessibility, food utilization and food system stability. Agriculture is important for having food security in two ways, it produces the food people eat and provides the primary source of livelihood for 36 percent of the world's total workforce (FAO, 2008). Agriculture and food security are inseparable and are also interlinked to poverty.

It is against the above backdrop that this paper examines the impacts of climate change on food security, agricultural sustainability practices and poverty with a view to offering viable and workable solutions to tackle the threats. Towards this end, the paper considers adaptation and mitigation. Policy options and interventions to address and curb the growing threats are also considered. 


\section{Objectives}

The key objective of this paper is to examine the impact of global climate change on food security. Linked to this key objective is how to showcase the various manifestations of climate change that affect farmers, especially in the developing countries where there is little or no resilience to the catastrophe. Consequently, the paper highlights how the impacts, such as drought, extreme rainfall, flooding and erosion are exacerbating the already worsening situation thereby creating and increasing poverty in developing countries.

\section{Methodology}

The methodology for this study was purely a qualitative research approach. Pursuant to this, the study relies extensively on the existing relevant literature and in the course of review, it was apparent that there was a knowledge gap in the area of climate threats to food security as a result of the impact of climate change. The key contributor to the threat is the emission of carbon dioxides as a result of human activities. To address this, the study looks at various existing strategic interventions put in place to reduce emissions and argues for immediate adoption.

\section{Observations and Discussion}

\subsection{Insights from the existing literature}

Today's world faces multiple challenges. The impact of global climate change has drastically increased the vulnerability of farmers, especially in most developing countries as they are unable to predict or forecast the weather accurately using their indigenous knowledge. Unfortunately this has been the practice for years (Salick and Byg 2007). However, this does not mean that the developed countries are immune to the devastating and unpredictable weather events. On a daily basis, reports of droughts, outbreaks of fire, heavy rainfalls and many more natural disasters that occur in both developing and developed countries constantly received through the media (Turner and Clifton 2009).

Undoubtedly, food insecurity remains endemic in most of the developing countries, particularly in Africa (Rosegrant and Cline 2003). According to Balogun et al. (2013) "The significance of this variability is clear when we consider that in sub-Saharan Africa, agricultural production accounts for up to $90 \%$ of food needs. Socio-economic conditions and the adverse impact of unpredictable weather on the agricultural production of communities in sub-Sahara Africa have long been recognized as an important cause of malnutrition in the region." There is also a consistent increase in the cost of food prices making the hunger situation unbearable for most people especially in the developing countries due to the frequency of the manifestation of the bizarre weather events called climate change on agricultural activities. The weather events have destroyed vital ecosystems, infrastructure, property, and people's livelihoods and sometimes result in fatality. These negative results of weather events produce poverty (Balogun et al. 2013).

Against the backdrop of these threats, there is need for viable and working solutions to address the threats of food insecurity which may lead to the problem of scarcity of food and throw a lot of people into hunger and abject poverty (Pfeiffer, 2006).

Therefore, this calls for development that will also incorporate the issue of food security in order to address poverty. This approach will promote sustained food security. In order to implement this, there should be a very strong institution that will be given the responsibility to carry out such task. India has made efforts in this regard to promote food security by enabling people to engage in economic activities that will create wealth and lead to technological progress. India has designed and established crop insurance scheme to absorb the impact of climate change should it manifest (Mills, 2007). Crop insurance is therefore playing an important role in supporting Indian farmers through the losses incurred during drought years (de la Fuente, 2007). It seems as if crop insurance is a possibility that countries will have to consider as an adaption measure to protect farmers and as a result reducing poverty caused by climate change (Linnerooth-Bayer and Mechler 2006). Other developing countries are therefore encouraged to emulate what India is doing to assist farmers to continue to be in business of farming.

Against the backdrop of the above challenges, the international community and the policy makers are enjoined to refocus on sustain food security by incorporating green agriculture as a solution to several of these challenges, including hunger, poverty, unemployment and environmental degradation (Sha Zukang, 2012).

New climate threats are also emerging on a daily basis. , If no action is taken to combat the surge, it might affect progress in human development achieved over the last decade and slow down or even reverse economic growths 
successes recorded by some of the developing countries (Daily and Ellison 2002).

While it is conceded that managing climate risks is a major challenge of today and for the future, the high dependence of the economies and rural people upon rain fed agriculture, the prevalence of poverty and food insecurity, and limited development of institutional and infrastructural capacities make coping with natural climate variability a perennial challenge (Speranza, 2010). . In the past several decades, the numbers of extreme weather events in particular sub regions and the numbers of people affected by droughts and floods have grown dramatically (Endfield and Tejedo 2006). Climate change indeed poses a grave threat, with a range of devastating consequences for humanity, and that restricting emissions now is the best response to that threat (Shearman and Smith 2007).

Scientific evidence has shown that as climate change becomes a more serious threat to agricultural production worldwide, existing agricultural systems are being questioned (Dimes et al. 2008). Christian-Smith (2012) has indicated that these systems will face even greater challenges in the future, in terms of both mitigation and adaptation to climate change. As a greenhouse gas emitter and a producer of food for a steadily increasing world population, the agricultural sector is increasingly being recognized as part of both the challenge and the solution. The study conducted by Parrt et al. 2009 for World Food Programme revealed that climate change will act as a multiplier of existing threats to food security, make natural disasters more frequent and intense, land and water more scarce and difficult to access, and increases in productivity even harder to achieve, thereby creating unbearable hunger and poverty. The implications of these are that people who are poor, have lack food insecurity and are malnourished will become more immense and the poor will become chronically poorer (Parry et al. 2009).

Therefore, the need for constant assessment of the impact and effects of global climate change on agriculture and food production should be top priority of most of the governments. The developing countries should be more proactive in this regard considering the fact that they are the most vulnerable to global climate change (Patwardhan and Semenov 2007). The relieving news is that previous studies have shown that investment in agricultural research has high rates of return both in terms of returns and poverty reduction (Diao et al. 2008). India has invested hugely on climate crop and climate crop insurance. These are now having a huge resilient on the negative impact of climate changes. This model is therefore making food production and food security feasible. The effects are being felt by the poor because a lot of them now have access to food and at the same time, the farmers are more productive leading to increase in profits due mainly to strategic interventions that are now mitigating and adapting to global climate change calamities and catastrophes (Nath and Behera 2011).

\subsection{Adapting Food Production to Climate Change}

The risks and vulnerability of the farmers and agricultural stakeholders will reduce if they take active steps to adapt tactical and strategic planning to these evolving climate risks (Smit and Pilifosova 2003). In sub-Saharan Africa, a lot needs to be done in view of the huge vulnerability the continent faces (Ellis, 2005). Already, there is huge magnitude of poverty, food security, environmental and health challenges that are faced in sub-Saharan Africa, adaptation to climate change should not and cannot be divorced from those current development priorities (Brauch, 2011). Therefore, any development plan to be implemented should take into consideration food security. More importantly, the principles inherent in sustainable development which tacitly supports a holistic development where resources are used for current and future generations should also play a prominent role in food sustainability (Shah and Strong 2000).

Climate change is likely to make matters worse with increases in rainfall variability being predicted (Mendelsohn and Dinar, 1999). The ability of agricultural communities and agricultural stakeholders to cope better with the constraints and opportunities of current climate variability must first be enhanced for them to be able to adapt to climate change and the predicted future increase in climate variability (Twomlow, 2008).

It is therefore worthy to mention that, inaction will compound the existing problem with regards to the threats of climate change. Interventions in various ways would curtail the threats if not totally curb them. Thus so far, according to Food and Agriculture Organization of the United Nations (FAO, 2008) "Agriculture is a source of climate change but also a solution to climate change if adequate sustainable production measures are adopted that hold substantial mitigation potential, and that contribute to adapt agriculture and food production systems to extreme events, raising temperatures, and increasing CO2 concentration." FAO (2008) indicated that, in order to adapt to climate change, "farmers will need to broaden their crop genetic base and use new cultivars and crop varieties. They will need to adopt sustainable agronomic practices such as shift in sowing/planting dates, use of cover crop, live mulch and efficient management of irrigation and reduce the vulnerability of soil based agricultural production systems through the management of soil fertility, reduced tillage practices and management of the cycle of soil organic carbon more efficiently in grasslands and cropping 
systems."

Tackling threats to food security and preventing hunger and poverty should be a major concern to everybody (Clover, 2003). It cannot be the problem and concern of government and farmers alone. It should involve the support of everybody and those whose activities are causing global climate change. As part of the adaptation strategy, scientific and indigenous people should be seen to be working together especially in the areas of knowledge sharing and collaboration. After all, positive result that will increase food production and reduce hunger and poverty is the main goal of all the stake and role players (Uvin, 1995). Pursuant to this, tackling the problem of global climate change causing food insecurity, hunger and poverty, the best modern agricultural science will need to be combined with the best traditional knowledge. And the outcome needs to benefit smallholders, especially farmers in the developing countries farming in the remote rural isolated areas (Inclusive et al. 2010).

While scientific agricultural practices will, through constant technology innovations come up with the use of new cultivars and crop varieties to increase food production, the idea of adapting to climate impacts is not new to the local indigenous people (Brookfield and Padoch 2010). Traditionally, coping mechanisms for adapting to seasonal and annual climate variability include sharing local knowledge on varieties, farming systems, management technologies etc. but the need to increase production, coupled with the speed and magnitude of the expected changes in climate, poses new challenges (Bolin, 2001).

Even though, over the centuries, indigenous farming communities have learned to adjust to environmental changes and climate variability based on indigenous weather forecast knowledge skills acquired over the years (Mengistu, 2011), the current speed and intensity of climate change are outpacing their capacity to adapt. Crop failures and livestock deaths are causing economic losses, raising food prices and undermining food security with ever-greater frequency, especially in parts of sub-Saharan Africa (Benson, 1998). At the same time, demand for food is increasing as populations grow and dietary habits are constantly changing (Belasco and Horowitz 2009).

This is where coherence is most important. Without a coherent agricultural system that includes social safety nets in the short-term as well as investment in agriculture over the longer-term, including the strengthening of markets that reach smallholder farmers, we cannot achieve the goals we have set, and poverty and hunger will continue to be a problem (FAO 2011).

Agriculture is the main livelihood of the rural poor. A renewed effort should be made towards the importance of assuring resilience and sustainability of smallholders and supporting vibrant rural spaces in the development of nations, especially those where agriculture is the primary livelihood for a significant proportion of the population (Thompson et al. 2007).

Agriculture remains crucial for pro-poor economic growth in most African countries, as rural areas support $70-80 \%$ of the total population more than in any other sector (Von-Braun 2007). Therefore, investments and improvements in agricultural ventures and performance have the potential to increase rural incomes and purchasing power for large numbers of people to lift them out of chronic and abject poverty (Borlaug 1995).

\section{Climate Induced Poverty Reduction through Innovative Interventions}

It is generally accepted that climate change is a serious risk to poverty reduction and threatens to undo decades of development efforts (Newell and Jenner 2009). The UN Millennium Campaign was based on the notion that we cannot fight climate change without considering the rising energy needs of people from developing countries, nor can we effectively address global poverty without accounting for the impacts of climate change on agriculture, disease patterns and severe weather events, all of which particularly impact the poorest countries. They are more vulnerable because of their high dependence on natural resources, and their limited capacity to cope with climate variability and extremes (Adger, 2003).

\subsection{Sustained Agriculture for Food Security}

Food security is a function of several interacting factors starting from the farmers and includes food production as well as food purchasing power (Harrigan, 2008). Climate change is now worsening the prevalence of hunger through direct negative effects on production and indirect impacts on purchasing powers (Ziervogel and Ericksen 2010).

The negative impacts of climate change on food security are now a real concern (Parry et al. 1999). Addressing these complex challenges, with opportunities to harness new innovations, will require out-of the-box solutions (technology, institutions, policies, and higher investment) (Lybbett and Sumner 2010). The production losses for sub- 
Saharan countries could be substantial as the length of suitable growing period's decreases (Ruttan, 2002).

Tools and approaches are now available that allow for a better understanding, characterization and mapping of the agricultural implications of climate variability and the development of climate risk management strategies specifically tailored to stakeholders needs (Smit and Wandel, 2006).

\subsection{Improve Agricultural Biodiversity to increase Productivity}

As part of the solution to the problem, a way out is through agricultural biodiversity and tree biodiversity. Agricultural biodiversity is the variability of crops and their wild relatives, trees, animals, microbes and other species that contribute directly or indirectly, to food production. But climate change is threatening the existence of species as they are now shrinking and decreasing on a daily basis (Javis et al. 2008).

As part of adaptation strategy, knowledge in agricultural biodiversity can be effective for smallholder farmers who need tools and knowledge to overcome new world challenges, it also has the potential to change lives and sustain our world by diversifying livelihoods, increasing the resilience and sustainability of production systems and by providing access to a diverse and nutritious diet (Verchot et al. 2007).

Traditional coping mechanisms would not be sufficient to ensure food security and prevent effects on nutritional status but rather they must be complemented by the introduction of technical innovations and enabling frameworks (Eide et al. 1991). Efforts should therefore be geared towards research and innovation on the breeding of new and adapted varieties as well as the preservation of traditional, locally adaptable varieties that can tolerate climate variability and are suitable for changed climatic conditions (Biringer et al. 2007). This is achievable through the development of innovative but practical technologies such as alternative cropping systems, conservation and precision agriculture, and sustainable forest management; and the application and improvement of technologies for more efficient use of inputs such as energy, fertilizer, water, seeds (Sayer and Campbell 2004). It also suggested that for all technological innovations in agriculture it was crucial that they would be easily accessible and affordable for the communities in need and that adaptation strategies must also be supported by strong institutions and enabling policy and legal frameworks (Batterbury and Warren 2001).

\subsection{Anticipation and Preparedness toward Climate Calamities}

While it is very important to promptly respond to the climate crises whenever they do manifest, effective management driven by anticipation and preparedness will provide better solution to the problem (Coombs, 2011). In order to achieve this, the following suggestions have been made, knowledge and understanding of risks and who the victims are; monitoring and evaluation of the risks to ascertain and forecast; taking care of the poor of the poorest and ensure food security and availability to them during disaster, linking all developments plans to climate change mitigation and adaptation, availing people on climate information and issues surrounding disasters to the community and decision makers, adequate provisions of financial resources and human resources for effective risk reduction is very important (Adger, 2006).

\section{Conclusion}

Considering that carbon emissions causing global climate change are not likely to decrease anytime soon, the consequences will always be manifestation of destructive weather event. This has been impacting devastative on agricultural activities of all types. Hunger is on the increase and poverty is being produced on a daily basis. This is a huge concern for policy makers and role players. The time has now come for drastic reduction in emissions so that we can have stable and clean environment. People need food to survive; negative impact of climate change is affecting food security and production. Hence, holistic application of sustainable development which also applies to agriculture should be pursued vigorously in order to have sustainable livelihood.

\section{Recommendations}

The time has now come to strengthen implementation of policies and laws on emissions reduction. There is a linkage between food, the environment and climate change. Disaster is now threatening this linkage hence the need to do more and ensure that the vulnerable people are protected. Sincere political will on the part of the leaders is therefore needed to 
reduce strategically human activities causing global climate change that is destroying agriculture and livelihoods.

\section{Acknowledgements}

This is a heavily revised version of the paper presented at the Strategies to overcome poverty and inequality: Towards Carnegie III at University of Cape Town, Cape Town, South Africa, 3- 7 September 2012. I take this opportunity to thank participants at the conference for their useful comments. I would also like to thank the participants at the conference for their useful comments. I would also like to thank Eskom Tertiary Education Support Programme (TESP), South Africa in collaboration with Fort Hare Institute of Technology, University of Fort Hare, Alice, Eastern Cape for the assistance provided to undertake this research work.

\section{References}

Adger WN 2003. Adaptation to climate change in the developing world, Progress in Development Studies, 3(3):179-195.

Adger WN 2006. Vulnerability, Global Environmental Change, 16(3):268-281.

Adger WN, Dessai S, Goulden M, Hulme M, Lorenzoni I, Nelson DR, Naess LO, Wolf J, Wreford A 2009. Are there social limits to adaptation to climate change? Climatic Change, 93(3): 335-354.

Balogun OL, Yusuf SA, Ayantoye K 2013.The Threats of Climate Change: Implication for Food Crisis in Sub-Sahara Africa, Sustainable Food Security in the Era of Local and Global Environmental Change, 1:85-98.

Batterbury S, Warren A 2001. The African Sahel 25 years after the great drought: assessing progress and moving towards new agendas and approaches, Global Environmental Change, 11(1):1-8.

Belasco WJ, Horowitz R 2009. Food chains: From farmyard to shopping cart, University of Pennsylvania Press, Philadelphia, USA.

Benson C 1998. The Impact of Drought on Sub-Saharan African Economies: Preliminary Examination, Publication of the World Bank, Washington, USA.

Biringer J, Guariguata MR, Locatelli B 2005. Biodiversity in a changing climate: a framework for assessing vulnerability and evaluating practical responses to Climate Change, CIFOR Publishers, Jakarta, Indonesia.

Bolin B 2001. Key features of the global climate system to be considered in analysis of the climate change issue, Cambridge University Press, Cambridge, UK.

Borlaug NE. Dowswell CR 1995. Mobilising Science and Technology to Get Agriculture Moving in Africa, Development Policy Review, 13(2):115-129.

Brauch HG 2011. Coping with global environmental change, disasters and security: threats, challenges, vulnerabilities and risks, Springer Publishers, Berlin, Germany.

Brookfield H, Padoch C 2010. Appreciating Agrodiversity: A Look at the Dynamism and Diversity of Indigenous Farming Practices, Environment: Science and Policy for Sustainable Development, 36(1):6-45.

Brusasco-Mackenzie M 2002. Environment and Ssecurity, Earthscan Publications Ltd, London.

Chakraborty S, Newton AC 2011. Climate change, plant diseases and food security: an overview, Plant Pathology, 60(1):2-14.

Christian-Smith J 2012. Water and Agriculture-A Twenty-First Century US Water Policy, 2012. Oxford University Press, UK.

Clover J 2003. Food security in sub-Saharan Africa, African Security Review 12(1):5-15.

Coombs WT 2011. Ongoing crisis communication: Planning, managing, and responding SAGE Publications, Thousands Oakes, California, USA.

Daily G, Ellison K 2002. The new economy of nature: the quest to make conservation profitable, Island Press, Washington, USA.

de la Fuente A 2007. Private and Public Responses to Climate Shocks. From. https://hdr.undp.org/en/reports/global/hdr20072008/papers/de\%20la\%20Fuente_Alejandro_2007a.pdf. (Retrieved August 4, 2012).

Dellapenna J W 2008. Climate Disruption, the Washington Consensus, and Water Law, Temple Law Review, 81:383-392. Diao X, Headey D, Johnson M 2008. Toward a green revolution in Africa: what would it achieve, and what would it require? Agricultural Economics, 39(1):539-550.

Dimes J, Rao KPC, Shapiro B, Shiferaw B, Twomlow S 2008. Coping better with current climatic variability in the rain-fed farming systems of sub-Saharan Africa: An essential first step in adapting to future climate change? Agriculture, Ecosystems \& Environment, 126(1): 24-35.

Eide A, Oshaug A, Eide WB 1991. Food Security and the Right to Food in International Law and Development, Transnational Law and Contemporary Problems, 1:415-423.

Ellis F 2005. Small farms, livelihood diversification, and rural-urban transitions: Strategic issues in Sub-Saharan Africa. From http://portal.iri.columbia.edu/C80BD74C-6628-40C5-907D-6C6F7475BE16/FinalDownload/Downloadld. (Retrieved November 8, 2011).

Endfield GH, Tejedo IF 2006. Decades of Drought, Years of Hunger: Archival Investigations of Multiple Year Droughts in Late Colonial Chihuahua, Climatic Change, 75(4):391-419.

FAO 2008. Food and Agriculture Organization of the United Nations. Joint FAO/WHO activities on Risk Assessment of Microbiological Hazards From foodshttp://www.who.int/foodsafety/micro/jemra/meetings/call_data_formula_08.pdf. (Retrieved March 8, 2012). 
FAO 2011. Food and Agriculture Organization of the United Nations. Price Volatility in Food and Agricultural Markets: Policy Responses. From http://www.amis-outlook.org/fileadmin/templates/amis/documents/interagency_report_to_the_g20_on_food_price_volatility .pdf. (Retrieved January 7, 2013).

Fischer G, Shah M, Van Velthuizen H 2002. Climate change and agricultural vulnerability. From http://indiaenvironmentportal.org.in /files/climate\%20change\%20agri\%20vulnerability\%20jb-report.pdf. (Retrieved July 9, 2011).

Gregory PJ, Ingram JSI, Brklacich M 2005. Climate change and food security, Philosophical Transactions, 360(1463); $2139-2148$.

Hans G. Bohle, Thomas E. Downing, Michael J. Watts 1994. Climate change and social vulnerability: Toward a sociology and geography of food insecurity, Global Environmental Change, 4(1):37-48.

Harrigan J 2008. Food insecurity, poverty and the Malawian Starter Pack: Fresh start or false start? Food Policy, 33(3):237-249.

Hofisi C, Chigavazira B, Mago S, Hofisi M 2013. Climate Finance Issues: Implications for Food Security in Southern Africa, Climate Change Adaptation, 4(6): 47-53.

Inclusive C, Needs R, Savings RD, Maize DH 2010. Thematic Focus: Climate Change, Agriculture and Food Security. From http://cgiar.bio-mirror.cn/c80bd74c-6628-40c5-907d-6c6f7475be16/finaldownload/. (Retrieved February 4, 2012).

Jarvis A, Upadhyaya H D, Gowda C L L, Agrawal P K, Fujisaka S, Anderson B 2008. Climate change and its effect on conservation and use of plant genetic resources for food and agriculture and associated biodiversity for food security. From http://oar.icrisat.org/5810/. (Retrieved October 4, 2012).

Kelly PM, Adger WN 2000. Theory and Practice in Assessing Vulnerability to Climate Change and Facilitating Adaptation, Climatic Change, 47(4): 325-352.

Linnerooth-Bayer J, Mechler R 2006. Insurance for assisting adaptation to climate change in developing countries: a proposed strategy, Climate Policy, 6(6):621-636.

Lybbett T, Sumner D 2010. Agricultural technologies for climate change mitigation and adaptation in developing countries: policy options for innovation and technology diffusion. From http://dspace.cigilibrary.org/jspui/handle/123456789/29144. (Retrieved September 9, 2012).

Mendelsohn R, Dinar A 1999. Climate Change, Agriculture, and Developing Countries: Does Adaptation Matter? Oxford Journals, 14(2): 277-293.

Mengistu DK 2011. Farmers' perception and knowledge of climate change and their coping strategies to the related hazards: Case study from Adiha, central Tigray, Ethiopia, Agricultural Science, 2(2):138-145.

Mills E 2007. Synergisms between climate change mitigation and adaptation: an insurance perspective, Mitigation and Adaptation Strategies for Global Change, 12(5):809-842.

Nath PK, Behera B 2011. A critical review of impact of and adaptation to climate change in developed and developing economies, Environment, Development and Sustainability, 13(1):141-162.

Nellemann C 2009. The Environmental Food Crisis: The Environment's Role in Averting Future Food Crises: a UNEP Rapid Response Assessment. From http://zpc5uabqx\&sig=ywykh99a5d3206sjwfoifo2ria8\#v=onepage\&q\&f=false. (Retrieved September 6, 2012).

Newell P, Jenner N Baker L 2009. Governing Clean Development: A Framework for Analysis, Development Policy Review, $27(6): 717-$ 739.

Parry M, Rosenzweig C, Iglesias A, Fischer G, Livermore M 1999. Climate change and world food security: a new assessment, Global Environmental Change, 9(1):51-S67.

Parry M, Evans A, Rosegrant MW, Wheeler T 2009. Climate change and hunger: Responding to the challenge, WFP Publishers, Viola, Italy.

Patwardhan A, Semenov S 2007. Assessing key vulnerabilities and the risk from climate change. From http://ensembleseu.metoffice.com/c80bd74c-6628-40c5-907d-pdf. (Retrieved April 4, 2011).

Pfeiffer DA 2006. Eating fossil fuels: oil, food and the coming crisis in agriculture, New Society Publishers, Gabriola Island, Canada.

Rosegrant MW, Cline SA 2003. Global Food Security: Challenges and Policies, Science Journal, 12(302):1917-1919.

Ruttan VW 2002. Productivity Growth in World Agriculture: Sources and Constraints, The Journal of Economic Perspectives, 16(4):161184.

Salick J, Byg A 2007. Indigenous peoples and climate change. From http://www.tyndall.ac.uk/sites/default/files/Indigenous\%20Peoples \%20and\%20Climate\%20Change_0.pdf. (Retrieved June 4, 2013).

Sayer J, Campbell B 2004. The science of sustainable development: local livelihoods and the global environment, Published by the Press Syndicate of the university of Cambridge, Cambridge, UK.

Shah MM, Strong MF 2000. Food in the 21st century: from science to sustainable agriculture, Publication of the World Bank, Washington, USA.

Shearman DJC, Smith JW 2007. The climate change challenge and the failure of democracy, Prager Publication, New York, USA.

Smit B, Wandel J 2006. Adaptation, adaptive capacity and vulnerability, Global Environmental Change, 16(3):282-292.

Smit B, Pilifosova O 2003. Adaptation to climate change in the context of sustainable development and equity. From https://www.vie.unu.edu/file/get/9995.pdf. (Retrieved August 6, 2012).

Speranza C I 2010. Resilient Adaptation to Climate Change in African Agriculture. From http://dspace.cigilibrary.org/jspui/handle /123456789/29511. (Retrieved July 19, 2012).

Storm S 2009. Capitalism and Climate Change: Can the Invisible Hand Adjust the Natural Thermostat? Development and Change, 40(6):1011-1038.

Thompson J, Millstone E, Scoones I, Ely A, Marshall F 2007. Agri-food System Dynamics: pathways to sustainability in an era of 
uncertainty. From. http://opendocs.ids.ac.uk/opendocs/handle/123456789/2472. (Retrieved July 16, 2012).

Turner NJ, Clifton 2009.It's so different today": Climate change and indigenous life ways in British Columbia, Canada, Global Environmental Change, 19(2):180-190.

Twomlow S, Mugabe FT, Mwale M, Delve R, Nanja D, Carberry P, Howden M 2008. Building adaptive capacity to cope with increasing vulnerability due to climatic change in Africa-A new approach, Physics and Chemistry of the Earth, 33(8):780-787.

Uvin P 1995. Fighting hunger at the grassroots: Paths to scaling up, World Development, 23(6):927-939.

Verchot LV, Van-Noordwijk M, Kandji S, Tomich T, Ong C, Albrecht A, Mackensen J, Bantilan C, Anupama KV, Palm C 2007. Climate change: linking adaptation and mitigation through agroforestry, Mitigation and Adaptation Strategies for Global Change, 12(5):901-918.

Von-Braun J 2007. The World Food Situtation: New Driving Forces and Required Actions, International Food Policy Research Publication, Washington, USA.

Ziervogel G, Ericksen PJ 2010. Adapting to climate change to sustain food security, Climate Change, 1(4):525-540. 